\title{
CONSTITUTIONALITY OF DIRECT ACTION LAWS IN A MULTISTATE CONTEXT: GOVERNMENTAL INTEREST AND THE CONFLICT OF LAWS *
}

IN order to facilitate the compensation of accident victims, several states have enacted "direct action" laws allowing such victims to sue a tort-feasor's liability insurer without first obtaining judgment against the tort feasor." These statutes impose direct action provisions upon specified liability insurance policies made within the state. ${ }^{2}$ Louisiana has the broadest and most explicit of these laws. Its law applies both to all liability contracts made within the state, and to all accidents in the state, regardless of where the policies are written. $^{3}$ In addition, foreign insurance companies must file written consent to direct action in order to do business in Louisiana." These direct action

*Watson v. Employers Liab. Assurance Corp., 348 U.S. 66 (1954).

1. As used herein, "direct action" means an action by the injured party directly" against the insurance company, whether alone or joined with the insured. Direct action after reduction of the claim to judgment is specifically provided for by the present standard liability policy. 1 American Bar Association Section of Insurance law, Insurance Policy Annotations, pt. 1, pp. $42-43$ (Supp. 1945) (hereinafter cited as ABA Insurance Annotations). But direct action against the insurer before reduction of the claim is specifically forbidden in the standard policy. Ibid. See text at notes 9-10 infra.

2. Those specified may be all policies written in the state, or only all policies insuring motor carriers. See note 4 infra. Even if policies are written without such requircd provisions, these will be read into them. Dean v. Bituminous Cas. Corp., 72 F. Supp. 801 (W.D. La. 1947) ; Jacobsen v. Howard, 164 Okla. 88, 23 P.2d 185 (1933).

3. LA. Rev. Stat. ANN. § $22: 655$ (1950). Section $22: 655$ and its predecessors fairly clearly impose a "right of direct action" upon all insurance policies "issued or delivered" in Louisiana. Louisiana courts implicitly, though not squarely, recognized this right in suits involving Louisiana contracts and foreign accidents. See, e.g., Burke v. Massaclutsetts Bonding \& Ins. Co., 209 La. 495, 24 So. 2d 875 (1946); Reeves v. Globe Indenunity Co., 185 La. 42 , 168 So. 488 (1936). A 1950 amendment to the Louisiana law states: "This right of direct action shall exist whether the policy sued upon was written or delivered in the State of Louisiana or not and whether or not such policy contains a provision forbidding such direct action, provided the accident or injury occurred within the State of Louisiana." LA. Rev. Stat. AnN. § $22: 655$ (1950) (emphasis added). This section was intended to expand the direct action law to apply to all contracts covering Louisiana accidents, apparently in response to Belanger v. Great American Indemnity Co., 89 F. Supp. 736 (E.D. La. 1950), which held that the law did not apply to forcign no action contracts. See Weingartner v. Fidelity Mut. Ins. Co., 205 F.2d 833 (5th Cir. 1953) (concurring opinion). But in Weingartner, the Fifth Circuit read the phrase emphasized above to mean that the law was no longer intended to apply to foreign accidents, even though it admitted that the law prior to the amendment was so applicable. Ibid. Since the purpose of the 1950 amendment was to expand rather than to narrow the scope of the direct action law, the law should be held applicable to foreign accidents.

4. La. Rev. Stat. ANn. $\$ 22: 983$, para. E (1950). Louisiana also requires insururs to designate the Secretary of State as their agent for receipt of stubstituted scrvice of process. La. Rev. Stat. ANn. $\$ \S 22: 982(8), 22: 985$ (1950).

Besides the Louisiana law, similar laws exist in a number of other states. Wisconsin 
laws favor the injured party by providing a convenient defendant in the case of an out-of-state tort-feasor, ${ }^{\mathbf{5}}$ by eliminating a possible second suit against the insurer after judgment against the insured, ${ }^{\mathbb{C}}$ and by exposing the insurer to the jury. ${ }^{7}$

requires liability insurance to provide that the insurer shall be liable directly to injured persons, WIs. StaT. $\$ 85.93$ (1953), Heinzen v. Underwriters Cas. Co., $20 S$ Wis. 512, 243 N.W. 448 (1932), and also provides that liability insurers may be joined as deiendants with insured tort feasors, Wis. Stat. $\$ 260.11$ (1953), Oertel v. Williams, 214 Wis. 68 , 251 N.W. 465 (1933). See Comment, 1953 Wis. L. Rev. 6SS.

Rhode Island provides that injured parties may proceed direetly against the insurer in the event that no process can be served against the insured, but joinder is specifically forbidden. RI. GEN. LAws c 155, \$ 1 (1938). Direct action against the insurer has been allowed in other states in connection with compulsory insurance for public motor carriers. GA. CoDE ANN. $\$ \S 68-509,68-612$ (Supp. 1951) (joinder); Iown Cone A:x: \& 325.26 (Supp. 1951) (direct action where no process on insured); Wasr. Rev. Cone $\S$ 81.72 .060 (1951) (joinder).

In other states joinder has been permitted by implication of compulsory insurance laws. Graves v. National Mut. Cas. Co., 164 Kan. 267, 188 P.2d 945 (1948); Massey v. War Emergency Co-operative Ass'n, 209 S.C. 292, 39 S.E.2d 907 (1946). But cf. American Fidelity \& Cas. Co. v. McClendon, 125 Tex. 41, 81 S.W.2d 493 (1935).

There seems to be a tendency in other states to limit rather than expand the scope of direct action. See, e.g., North Carolina: Williams v. Fredericlsson Motor Express Lines, 195 N.C. 682, 143 S.E. 256 (1928), N.C. Gen. Stat. \& 62-121.61 (1950) (legislative prohibition of joinder); Alabama: Baggett v. Jackson, 244 Ala. 404, 13 So. 2d 572 (1943) (law changed to provide that insurer is liable only to pay "any final judgment"); West Virginia : Cramblitt v. Standard Acc. Ins. Co., 116 W. Va. 359, 180 S.E. 434 (1935), W. VA. CODE ANN. $\$ 1492$ (1949 and Supp. 1953) (statute authorizing joinder repealed).

See, generally, 8 Applearan, Insurance Law and Practice $\$ \$ 4861-66$ (1942).

5. This is so in the case where the foreign tort feasor is not subject to suit in the state. In the principal case, for example, it was a manufacturer who could not be served with process in Louisiana. Watson v. Employers Liab. Assurance Corp., 34S U.S. 66, 72 (1954). Out-of-state motorists, however, are subjected to local suit by the substituted service law. La. Rev. Stat. ANN. §§ 13:3474-75 (1950).

The general purpose of direct action laws is said to be the protection of the public. Davies v. Consolidated Underwriters, 199 La. 459, 476, 6 So. 2d 351, 357 (1942). The very wording of some such statutes reflects this purpose. Western Automobile Cas. Co. v. Burnell, 17 Tenn. App. 687, 690, 71 S.W.2d 474, 475-76 (1933) ("for the benefit of the public").

6. Although the standard liability policy provides that the insurer wi:l pay any final judgment against the insured, 1 ABA Insurasce ANxorstroxs, pt. 1, p. 23 , the insurer may be unwilling to perform the contract. The injured party may have to pruceed separately against the insurer, suffering the trouble and expense of a second suit, possibly in a distant forum, and running the chance that the insurer may successiully interpose defenses on its contract with the insured, such as non-cooperation or failure to give natice of loss. The insurer usually may not be deprived of such defenses in a direct suit. Sec La. Rev. Stat. Anw. \$22:655 (1950). But cf. West v. Monroe Bakery, 217 L3. 189, 46 So. 2d. 122 (1950).

7. The belief is widespread that exposure of the insurer to the jury increases the likelihood and the size of plaintiffs' verdicts. See, e.g., Belanger v. Great American Indemnity Co., 89 F. Supp. 736, 740 (IV.D. La. 1950), aff'd, 188 F.2d 196 (5th Cir. 1951); Appleman, Joinder of Policyholder and Insurer as Partics Defendant, 22 MInso. L. Rer. 75 (1938). But see 2 Wigmore, Enidence $\$ 282 a$ (3d ed. 1940). 
To the degree that direct action laws offer special protection to accident victims, they disadvantage the insurer, which must pay for that special protection. ${ }^{8}$ For this reason, insurers commonly insert in their contracts clauses forbidding direct action. ${ }^{\circ}$ These "no action" clauses are enforceable everywhere except where they are overridden by direct action laws. ${ }^{10}$

Insurance companies cannot avoid the direct action statute where the contract, the accident, and the suit all originate within the same state. ${ }^{11}$ But tort suits against insurers frequently involve the laws of several states, only one of which will usually have a direct action law. In these interstate situations, insurance companies have managed to avoid the operation of direct action laws by invoking conflict of laws doctrines or by raising constitutional objections.

Several conflict of laws formulae have been applied to these interstate problems, with inconsistent results. Some courts have characterized the direct action law as a "procedural" law of the forum and therefore have found it applicable to a foreign contract. ${ }^{12}$ And foreign courts have refused to apply the law because it was procedural, even though both accident and contract were in the direct action state. ${ }^{13}$ Some courts have refused to apply a direct action law on the grounds that it would modify "substantive" rights acquired under foreign laws $;^{14}$ and other courts have occasionally applied a foreign direct action law in the forum on the ground that it vested substantive rights. ${ }^{10}$ Again, where the place of contracting was different from the place of the tort,

8. The insurer rather than the plaintiff must bear the added expense of distant litigation; but this may not be an unexpected expense, since the insurer generally undertakes the defense of any suit against the insured.

For evidence that premium rates of Wisconsin insurance policies were raised as a result of the Wisconsin direct action law, see 2 Wisc. Legisl. Counclt, Report of rir Commitre on Motor Vehicle Accidents, pt. I, p. 6 (1952), cited in Comment, 1953 WIS. L. REv. 688, 715 n. 146.

9. 1 ABA Insurance Annotattons, pt. 1, pp. $42-43$ (Supp. 1945).

10. See 8 Applearan, Insurance Law and Practice 4851 nn.1, 4 (1942). Statutes specifying that there must be judgment against the insured before any action can lic against the insurer are not uncommon. Id. at 4852.

"No action," like its complementary term "direct action," see note 1 supra, is used herein to denote actions against the insurer before reduction of the claim against the insured.

11. See cases cited in note 4 supra.

12. Robbins v. Short, 165 So. 512 (La. App. 1936); Bouis v. Aetna Cas. \& Surety Co., 91 F. Supp. 954 (W.D. La. 1950); Oertel v. Williams, 214 Wis. 68, 251 N.W. 465 (1933).

13. Wells v. American Employers Ins. Co., 132 F.2d 316 (5th Cir. 1942); National Mut. Cas. Co. v. Blackford, 200 Ark. 847, 141 S.W.2d 54 (1940); McArthur v. Maryland Cas. Co., 184 Miss. 663,186 So. 305 (1939).

14. Bayard v. Traders \& Gen. Ins. Co., 99 F. Supp. 343, 354-55 (W.D. La. 1951): Bankers Indemnity Co. v. Bryant, 184 F.2d 1018, 1020 (10th Cir. 1950); Kilcuyne v. Trausch, 222 Wis. 528, 269 N.W. 276 (1936).

15. Kertson v. Johnson, 185 Minn. 591, 242 N.W. 329 (1932); Burkett v. Globe Indemnity Co., 182 Miss. 423, 181 So. 316 (1938), ozerruled, Mc.Irthur v. Marylaud Cas. Co., 184 Miss. 663, 186 So. 305 (1939). 
courts have sometimes characterized direct action as a matter of "tort"10 or of "contract"; such characterization has generally resulted in choice of the law of the place lacking a direct action statute. Finally, direct action has been held prohibited by the public policy of a non-direct action forum. ${ }^{18}$ As a rule, conflicts arguments have been more successful in avoiding foreign direct action laws than local ones.

When conflicts arguments have failed to avoid direct action, constitutional arguments have sometimes succeeded, where foreign no action policies were involved. The federal courts of Louisiana have been particularly receptive to these contentions. ${ }^{19}$ They have held that foreign insurers were denied equal protection of the laws by being exposed to juries in a state other than the one where the contract was made, ${ }^{20}$ and that allowing the direct action law to override foreign no action clauses constituted an impairment of contracts.:-

16. Hidalgo v. Fidelity \& Cas. Co., 104 F. Supp. 230, 231 (W.D. La. 1952), off'd, 205 F.2d 834 (5th Cir. 1953); Buxton v. Midwestern Ins. Co., 102 F. Supp. 500 (W.D. La. 1952).

17. Ritterbusch v. Sexmith, 256 Wis. $507,513,41$ N.W.2d 611, 614 (1950); Wheat v. White, 38 F. Supp. 796 (E.D. La. 1941).

18. Lieberthal v. Glens Falls Indemnity Co., 316 Mich. 37, 24 N.W.2d 547 (1946).

19. The Louisiana state courts, turning aside constitutional attacks, have reasoned that the direct action law was both procedural, Churchman v. Ingram, 56 So. $2 d 297$ (La. App. 1952), and substantive, West v. Monroe Bakery, 217 La. 189, 46 So. $2 d 122$ (1950), and have held it applicable both to foreign no action contracts, Robbins v. Short, 165 So. 512 (La. App. 1936), and to foreign accidents, Reeves v. Globe Indemnity Co., 185 La. 42, 168 So. 488 (1936).

The federal district courts first gave the direct action law a mixed rcception. Compare Wheat v. White, 38 F. Supp. 796 (E.D. La. 1941) (foreign law applicable to forcign no action contract), with Rogers v. American Employers Ins. Co., 61 F. Supp. 142 (IV.D. La. 1945) (Louisiana law procedural, and applicable). A slight modification of the wording of the law in 1948 resulted in a holding that it was no longer intended to apply to foreign contracts. Belanger v. Great American Indemnity Co., 89 F. Supp. 736 (ED. La. 1950), aff'd, 188 F.2d 196 (5th Cir. 1951). The Louisiana legisiature then passed a joint resolution declaring that it had never intended to change the law, 1SS F.2d at 197-98, and amended the law to make it specifically applicable to insurance policies wherever issued, La. Acts 1950, No. 541, § 1, LA. Rev. Stat. Aws. § 22:655 (1950). However, the federal courts then found that the direct action law was substantive, and held it unconstitutional when applied to foreign no action contracts. See, c.g., Bayard v. Traders \& Gen. Ins. Co., 99 F. Supp. 343 (WV.D. La. 1951), motion for newo trial dericd, 104 F. Supp. 7 (1952) ; Bish v. Employers Liab. Assurance Corp., 102 F. Supp. 343 (WV.D. La.), aff'd, 202 F.2d 954 (5th Cir. 1952), rev'd on rehearing (following the Supreme Court decision in the principal case), 217 F.2d 953 (1955); Fisher v. Home Indemnity Co., 198 F.2d 218 (5th Cir. 1952). But of. Buxton v. Alidwestern Ins. Co., 102 F. Supp. 500 (W.D. La 1952) (consent provisions of direct action law validate it). See Notes, 65 Harv. L. Rev. 688 (1952), 6 VANd. L. Rev. 775 (1953).

20. Bish v. Employers Liab. Assurance Corp., 102 F. Supp. 343, 347 (IW.D. La. 1652).

21. Ibid. The Wisconsin direct action law has also been held unconstiutional when applied to a foreign no action contract, on the ground of impirment of cuntract. Ritterbusch v. Sermith, 256 Wis. 507, 41 N.W.2d $611(1950)$. The usual rule is that there is no constitutional impairment of contract when the contract is made afier the law is enacted. Munday v. Wisconsin Trust Co., 252 U.S. 499 (1920); see text at note 27 irfro. 
Their firmest constitutional ground was the due process clause: the courts found that the direct action law could not be given extraterritorial effect to deprive insurers of substantial rights embodied in no action clauses valid in the state of contracting. ${ }^{22}$

In the recent case of Watson v. Employers Liability Assurance Corp.,$^{23}$ the Supreme Court ruled for the first time on the application of a direct action law to an out-of-state no action policy. ${ }^{24}$ Plaintiffs, residents of Louisiana, brought suit for injuries suffered there, from the use of Toni Home Permanents, against the manufacturer's liability insurer. ${ }^{25}$ Although the insurer had consented to direct action in Louisiana, the policy was executed in another state, and contained a no action clause valid there. ${ }^{26}$ The Court summarily rejected the equal protection and impairment of contracts arguments, reasoning that the law fell with equal force on all insurance companies doing business within the state and that the contract had been written after the law was enacted. ${ }^{27}$ In answer to the due process contention, it pointed out Louisiana's "legitimate interest" in providing medical care and economic assistance to accident victims within the state, and its corollary interest in insurance contracts designed to compensate such victims. ${ }^{28}$ The Court held these interests sufficient to justify the application of the direct action law to the foreign policy. ${ }^{20}$ It also found these interests substantial enough so that Louisiana was not compelled by the full faith and credit clause to "subordinate" its direct action law to the law of the state where the contract was made. ${ }^{30} \mathrm{~A}$ concurring opinion reasoned that the law should have been upheld on the narrower ground that Louisiana had the power to require the foreign insurer to consent to direct action as a condition of cloing business in the state, ${ }^{31}$ but the majority found that Louisiana could impose direct action whether the insurer consented or not. ${ }^{32}$

22. Bish v. Employers Liab. Assurance Corp., 102 F. Supp. 343, 348 (W.D. La. 1952) ; Belanger v. Great American Indemnity Co., 89 F. Supp. 736, 740 (E.D. La. 1950) ; Mayo v. Zurich Gen. Acc. \& Liab. Ins. Co., 106 F. Supp. 579, 581 (W.D. La. 1952).

23. 348 U.S. 66 (1954), reversing 202 F.2d 407 (5th Cir. 1953), and 107 F. Supp. 494 (W.D. La. 1952). The Watson case was the last of a series of similar cases in the fecleral courts of Louisiana. See note 19 supra.

24. In a companion case to Watson, the Court ruled that in a direct action by a Louisiana injured party against a foreign insurer alone, there was the diversity between real parties in interest requisite to federal jurisdiction. Lumbermen's Mut. Cas. Co. v. Elbert, 348 U.S. 48 (1954).

25. Watson v. Employers Liab. Assurance Corp., 348 U.S. 66, 67 (1954).

26. The policy was negotiated and issued in Massachusetts and delivered in Illinois, in both of which states the no action clause would have been valid. Id. at 67-68.

27. Id. at 70 .

28. Id. at 72-73.

29. Ibid.

30. Id. at 73.

31. Id. at 74 (Justice Frankfurter). The determination of whether a state cun requirc consent to direct action as a price of doing business in the state apparently also requires an assessment of the state's governmental interests. Frankfurter found the Louisiana consent requirement reasonable because "the conditions imposed are fairly related to the interests which Louisiana may appropriately protect in surrendering its right to exclude 
Since the foreign insurer in Watson had qualified to do business in Louisiana, it was clearly subject to suit there. ${ }^{33}$ But the Court's approval of direct action regardless of the insurer's consent suggests that a state may subject a foreign insurer to local suit and direct action even when it has not qualified to do business there. In order constitutionally to subject a foreign non-qualified corporation to suit within the state, the state must have certain "minimum contacts" with the corporation. 34 Louisiana law provides that issuance of an insurance policy to a Louisiana resident shall subject a non-qualified insurer to local suit, ${ }^{35}$ and issuance of such a policy may be a sufficient "contact" to make this constitutionally permissible. ${ }^{30}$ Moreover, Louisiana's direct action law applies to all insurance policies "delivered" in Louisiana," and since the governmental interest test is much like the "minimum contacts" test, W'afson may imply that a non-qualified insurer can also be subjected to direct action on a local policy. A more serious question would arise if $\mathrm{H}^{\mathrm{r}}$ alson were interpreted to imply that a policy simply covering Louisiana risks, even though issued by a non-qualified foreign insurer to a foreign insured, would permit the imposition of the direct action law. It could be argued that an insurance policy intended to compensate a local accident victim was a sufficient "contact" with the foreign insurer for the expression of Louisiana's governmental interest. If the Court in Watson had based its decision on the insurer's explicit consent to the direct action provision which Louisiana had a reasonable right to require as a condition of doing business, ${ }^{38}$ it would have avoided these jurisdictional implications.

The Supreme Court in deciding Watson was faced with two competing lines of decisions. In Hartford Accident \& Indcmmity Co. v. Delta \& Pine Land Co., ${ }^{39}$ it had considered whether Mississippi could impose its statute of

a foreign corporation." Id. at 82 . See cases cited id. at 74-83 (concurring opiniun), especially Washington v. Superior Court, 289 U.S. 361 (1933) (substituted service oi process a reasonable condition of doing business in the state).

32. Watson v. Employers Liab. Assurance Corp., 34S U.S. 66, 73-74 (1954).

33. See notes 4 and 26 supra, and accompanying text.

34. International Shoe Co. v. Washington, 326 U.S. 310,316 (1945); Parmalec v. Iowa State Traveling MIen's Ass'n, 206 F.2d 518, 521522 (5th Cir.), cert. deried, 346 U.S. 877 (1953).

35. LA. Rev. Stat. ANN. $\$ 22: 1253$ (1950); this is section 5 of the Uniform Unauthorized Insurers Act, 9A ULA 352 (1951). See Storey v. United Ins. Co.n 64 F. Sugp. 896 (E.D.S.C. 1946) (non-qualified insurer subject to suit under this section breause of a policy mailed to a local resident). Cf. Parmalee v. Iowa State Traveling Men's Ass'n, 206 F.2d 518 (5th Cir.), cert. denied, 346 U.S. 877 (1953) (similar law). However, the Fifth Circuit held a non-qualified insurer delivering policies within Louisiana was not subject to suit under this section. Employers Liab. Assurance Corp. v. Lejeune, 189 F.2J 521 (5th Cir.), cert. denied sub non. Lejeune v. Excess Ins. Co., 342 U.S. 869 (1951).

36. See Travelers Health Ass'n v. Virginia, 339 U.S. 643 (1950) (issuance of policy to local resident subjected non-qualified insurer to process for administrative procedding); accord, Parmalee v. Iowa State Traveling AIen's Ass'n, stipra note 35.

37. See note 3 supra.

38. See text at note 31 st:pra.

39. 292 U.S. 143 (1934). 
limitations on an insurance contract made in Tennessee and embodying a shorter limitation of action valid there. ${ }^{40}$ The Court found that Mississippi's interest in the contract was so slight as not to permit application of the statute, even though the risk insured against occurred in Mississippi and one of the parties had its principal place of business there. ${ }^{41}$ This case has been interpreted as holding that "extraterritorial" modification of a contract by a state other than the one where it is made violates due process. ${ }^{42}$ However, in Pacific Employers Insurance Co. v. Industrial Accident Commission, ${ }^{40}$ the Court had considered whether California could apply its workmen's compensation law to a Massachusetts employment contract where the injury occurred in California while the employee was temporarily located there. It held that California had sufficient governmental interest to apply its law in the face of a conflicting Massachusetts compensation statute.4 In Watson, the Court chose the Pacific Employers rationale and distinguished Hartford by emphasizing references made there to Mississippi's lack of interest in the contract. ${ }^{4 n}$ By assimilating Hartford to Pacific Employers, the Court may have laid to rest the extraterritorial concept of due process. ${ }^{46}$

Watson's extension of the governmental interest formula into the field of

40. Hartford Acc. \& Indemnity Co. v. Delta \& Pine Land Co., 292 U.S. 143 (1934).

41. Ibid. The federal courts of Louisiana found Hartford controlling with respect to the application of the Louisiana law to foreign contracts. Belanger v. Great American Indemnity Co., 89 F. Supp. 736, 739 (E.D. La. 1950) ; Bayard v. Traders \& Gen. Ins. Co., 99 F. Supp. 343, 355 (W.D. La. 1951).

42. See cases cited note 41 supra. See opinions in Order of United Conmercial Travelers v. Wolfe, 331 U.S. 586, 623, 628 n.2 (1947). But cf. Citizens Nat'l Bank v. Waugh, 78 F.2d 325, 326-27 (4th Cir. 1935). The Court in Watson called Harlford representative of the "extraterritorial concept of due process." Watson v. Employers Liab. Assurance Corp., 348 U.S. 66, 71 (1954).

43. 306 U.S. 493 (1939).

44. The facts in Pacific Employers were the converse of those in Alaskia Packers Ass'n v. Industrial Accident Comm'n, 294 U.S. 532 (1935), where the employment contract was entered into in California by California residents but the employment and the injury took place in Alaska. In Alaska Packers, Mr. Justice Stone expounded the governmental interest test which he later applied in Pacific Employers, holding that California's application of her workmen's compensation statute did not violate either clue process or full faith and credit. Pacific Employers, although it followed Alaska Packcrs, decided the validity of the law only in terms of full faith and credit. However, the Court there saitl that it was "not open to question" that in due process terms either state could apply its workmen's compensation statute. Pacific Employers Ins. Co. v. Industrial Accident Comm'n, 306 U.S. 493, 500 (1939). On these two cases and the governmental intercst test, see Notes, 39 Colum. L. Rev. 1024 (1939), 35 Colum. L. Rev. 751 (1935).

45. Watson v. Employers Liab. Assurance Corp., 348 U.S. 66, 71, 73 (1954). In Hartford, Mississippi's interest in the welfare of the injured party might well have been considered greatly diminished by the fact that that party had in effect waived the protection of the Mississippi statute of limitations by contracting for a shorter one.

46. Hartiord had previously been reconciled with the governmental interest approach. See Order of United Commercial Travelers v. Wolfe, 331 U.S. 586, 628 n.2 (1947) (dissenting opinion). 
liability insurance seems appropriate. ${ }^{77}$ State concern for the welfare of accident victims underlies the regulation of liability insurance as well as workmen's compensation. ${ }^{48}$ This formula should produce a desirable flexibilty in future decisions in the field. For while the extraterritorial due process concept tends to sanctify contract rights by preventing their modification in other states, the governmental interest test weighs the relative importance of such contract rights against a state's interests that may impinge upon those rights. In full faith and credit terms, the governmental interest test weighs competing states' interests in the protection of both accident victims and contracting parties."is And presumably it gives due regard to the comparative vigor with which the competing states have expressed their interests. ${ }^{\text {11 }}$

In Pacific Employers the Supreme Court suggested that either of tine states whose workmen's compensation laws were involved had sufficient interest in the welfare of the accident victim to apply its law to the injury in question without denying full faith and credit to the law of the other state. ${ }^{32}$ Since the interests of both states were of the same order, either could apply its own law.

47. Both Pacific Employers and Alaska Packers, see text and notes 43-44 suspra, involved workmen's compensation laws. See also Pink v. A.A.A. Highway Espress, Inc., 314 U.S. 201 (1911) (Georgia has sufficient interest to determine whether her citizens have become assessable members of a New York mutual insurance association). In other fields, however, the law of the state with the predominant interest is not always found controlling. See, e.g., Hughes v. Fetter, 341 U.S. 609 (1951) (wrongiul denth statute); Order of United Commercial Travelers v. Wolfe, 331 U.S. 586 (1947) (fraternal benefit society).

48. The states' special concern for the regulation of workmen's compensation and insurance has long been recognized. See New York Cent. R.R. v. White, 243 U.S. 188 (1917) (workmen's compensation); Prudential Ins. Co. v. Benjamin, 328 U.S. 408 (1946) (insurance).

49. See Hartford Acc \& Indemnity Co. v. Delta \& Pine Land Co., 292 U.S. 143, 150 (1934) (a state may not "enlarge the obligations of the parties" to a foreign contract). Justice Frankfurter's concurrence stated that IFatson allowed for the first time the "rewriting of a contract and enforcing it in a manner contrary tu the undertaking of the makers." Watson v. Employers Liab. Assurance Corp., 348 U.S. 60, 70 (1954). But in Pacific Enployers, a state was in fact allowed to vary contractual rights and duties arising elsewhere. See, also, F. A. Straus \& Co. v. Canadian Pac. RR., 254 N.Y. 407, 173 N.E. 564 (1930) (New York refused to enforce a limitation of liability in an English carrier contract).

50. Alaska Packers Ass'n v. Industrial Accident Comm'n, 294 U.S. 532, 547 (1935). The Court in Watson pointed out that Massachusetts had interests in the contract because it had been formally executed in that state and the insured had an office there. Watson v. Employers Liab. Assurance Corp., 348 U.S. 66, 73 (1954). Justice Franlifurter elaborated on these interests. Id. at 75 . The interests of a state in accident victims are discussed in the text at note 28 sitpra.

51. Thus, Pacafic Employers distinguished the earlier case of Bradford Elcetric Light Co. v. Clapper, 286 U.S. 145 (1932), partly on the basis that application in New Hampshire of the Vermont workmen's compensation law would not be "obnosiuns" tu the "policy" of New Hampshire, implying that New Hampshire could have had a folicy so explicit as to prevent the application of any law but its own. Pacific Employers Ins. Co. v. Industrial Accident Comm'n, 306 U.S. 493, 504 (1939).

52. Id. at $499-500$. 
But the interests to be balanced in a liability insurance transaction are not of the same order: interests in contracts and the rights of contracting parties must be balanced against interests in the welfare of injured persons. Watson seems to hold not that the competing interests were so evenly balanced that the forum could apply its own law, but that they were of unequal weight, and that the interests in the accident victim predominated. ${ }^{\text {b3 }}$

Watson forecloses most constitutional attacks on direct action laws and suggests certain constitutional limitations upon permissible conflict of laws decisions involving these laws. ${ }^{54}$ Watson decided that there is no constitutional barrier to the imposition of a direct action law by the state where the accident occurred, or where the victim is located. ${ }^{65}$ The case may mean that the interests of this state are so substantial that they must override the interests of the state where the no action contract is written even when suit is brought in the contract state..$^{58}$ However, the state where a contract is made also has a strong interest in insurance contracts written subject to its laws, ${ }^{67}$ and if these laws require direct action, it is doubtful that any state without such laws has sufficient interest to ignore the direct action law thus embodied in the contract. For even if the non-direct action state is the place of the accident

53. Watson v. Employers Liab. Assurance Corp., 348 U.S. 66, 72-73 (1954). Watson, by emphasizing the interests of the state of the accident and minimizing those of the state of contracting, follows Pacific Employers and Alaska Packers, see note 44 supra, in both of which the crucial governmental interests were in the injured person. Sce text at note 28 supra.

54. As to constitutional limitations on state conflict of laws decisions, see, generally, Cheatham, Federal Control of Conflict of Lazes, 6 VAND. L. REv. 581 (1953) ; Freund, Chief Justice Stone and the Conflict of Lazes, 59 Harv. L. Rev. 1210 (1946); Hilpert \& Cooley, The Federal Constitution and the Choice of Law, 25 WASH. U.L.Q. 27 (1939).

55. In Watson, the plaintiff was a resident of Louisiana and was also injured there. The Court did not consider separately the interests of the state where an accident occurs and those of the state where the victim resides, or must be cared for. The Court's language refers rather to the location of the accident than to the residence of the victim, Watson $r$. Employers Liab. Assurance Corp., 348 U.S. 66, 72 (1954); and the Louisiana law by its terms applies to local accidents rather than to local victims of accidents. See note 3 supra. But the governmental interests evoked by an accident seem to center in the victim rather than the place of the accident itself. See note 53 supra. It is possible that the state of the accident would have very little interest in fact, if the victim were not a resident and had never called upon that state for any sort of assistance.

In Wisconsin, Watson will undercut Ritterbusch v. Sexmith, 256 Wis. 507,41 N.W.2d 611 (1950), which held that the application of the Wisconsin law to a forcign no action policy was unconstitutional as an impairment of contract. See text and note 21 supra. The Wisconsin court might, however, fall back on the conflicts analysis it expounded there, to find that the law of the place of contracting governs. See text at notes 62-63 infra. Or the court might turn to WIs. Const. art. $1, \S 12$, which also prohibits impairment of contract.

56. See note 53 supra, and accompanying text. However, the forum is ordinarily allowed a certain latitude of deference to its own governmental interests. Sec Alaska Packers Ass'n v. Industrial Accident Comm'n, 294 U.S. 532, 547 (1935).

57. See Watson v. Employers Liab. Assurance Corp., 348 U.S. 66, 73 (1954); Pacific Employers Ins. Co. v. Industrial Accident Comm'n, 306 U.S. 493, 500 (1939). 
and therefore has a potential interest in accident victims, its laws forbidding direct action express not its interest in accident victims but its interest in protecting the contracting parties. And the latter interest seems to be less than that of the state of contracting. ${ }^{58}$ If the forum has no interest in either the injured person or the contract, ${ }^{59}$ it seems unlikely, following $W^{\prime}$ atson, that it will be permitted to apply its own direct action law to a no action contract, or to refuse to apply the direct action law of another state involved in the transaction. ${ }^{60}$ And in choosing between the laws of the states involved, the governmental interest test probably requires the forum to defer to that state whose law imposes direct action.

Whatever the constitutional limitations set down by WTatson, non-constitutional arguments may still be employed in dealing with direct action laws. The question whether a direct action law is intended to apply to a given interstate situation will continue to arise. ${ }^{.1}$ And conflict of laws doctrines may still be invoked. ${ }^{62}$ But courts deciding which conflicts rule to apply could profitably consider the $W$ atson rationale. Conflicts characterization resulting in a reference to place of the tort or place of contracting may recognize the underlying governmental interests of the state referred to. But a mechanical conflicts formula reflecting only a single interest is inadequate when, as in $I^{\circ}$ atson, not only tort rights but contractual and statutory rights are involved. ${ }^{03}$ For

58. Hughes v. Fetter, 341 U.S. 609 (1951), where a wrongiul death occurred in Illinois but Wisconsin had a predominant interest in the plaintiff, the decedent and the defendants, held that Wisconsin could not refuse to enforce the Illinois wrongiul deati statute in its courts. See also First Nat. Bank v. United Air Lines, 342 U.S. 396 (1952).

59. See Harmann v. United States Fidelity \& Guaranty Co., 6f F. Supp. 3to IW.D. La. 1946). The Louisiana law does not by its terms apply to such a transaction. See note 3 supra.

60. Courts have in the past refused to apply foreign direct action laws cren where both contract and accident had reference to the direct action state. Lieberthal v. Glens Falls Indemnity Co., 316 Mfich. 37, 24 N.W.2d 547 (1946); Wells v. Amerian Emgloyers Ins. Co., 132 F.2d 316 (5th Cir. 1942); MrcArthur v. Mraryland Cas. Co., 18t Miss. 6,3, 186 So. 305 (1939).

61. See Riding v. Travelers Ins. Co., 48 R.I. 433, 138 Atl. 186 (1927) (Rhode Island law not intended to apply to foreign policies); Weingartner v. Fidelity Mut. Ins. Co., 205 F.2d 833 (5th Cir. 1953) (Louisiana law not intended to apply to foreign accidents).

A preliminary inquiry concerning whether the Louisiana law was intended to apply to the transactions in question in McArthur and Wells, see note 60 supra, migit have avoided the results in those cases: characterizing the Louisiana law as procedural and therefore finding it inapplicable in a foreign forum.

62. See notes 12-1S supra. The law, for example, might be characterized as procedural by a foreign forum. But Watson's emphasis on the protection that the direet action law gave to injured parties implies that the Supreme Court feels the Lomisiana law at least to be substantive.

Wisconsin has both procedural and substantive statutory provisions for direct action. Recognizing this, the Minnesota court has still managed to avoid the effect of the law where both accident and contract were in Wisconsin, by "the application of a few simple rules of the conflict of laws." Anderson v. State Farm Mfut. Autu Ins. Cu., 222 Minu. 428 , 432, 24 N.W.2d 836,839 (1946).

63. The insurer's rights and duties are governed by contract, and yet they have reforence to the possible occurrence of a tort. The injured party's rights are essentially tort 
formal recognition of one state's interest precludes recognition of the interest of any other state. Watson suggests that in making such conflicts characterizations courts should weigh all the governmental interests involved. It further suggests that before a forum can refuse to enforce foreign rights on grounds of its public policy, it must first determine whether the governmental interests underlying that policy are sufficient to justify its refusal. ${ }^{34}$ Application of governmental interest criteria to conflicts decisions involving direct action laws should achieve greater uniformity in result than these decisions have hitherto manifested, ${ }^{65}$ for the weight of the governmental interests on each side of the scales should not vary with the forum.

rights, yet every liability policy extends a contractual right to injured third parties to sue under the contract. See note 1 supra. And states can and do impose by statute different and additional rights and duties-direct action among them-upon both contracts negotiated and torts occurring within their boundaries.

64. In Lieberthal v. Glens Falls Indemnity Co., 316 Mich. 37, 24 N.W.2d 547 (1946), the court held that Michigan public policy forbade direct action against an insurer, even though the suit involved both a Wisconsin accident and a Wisconsin contract. If a governmental interest argument were to be made, the result might be different, even though Michigan had an interest in the injured party, a resident of that state. See text at note 58 supra.

65. See cases cited notes 12-18 supra. Uniformity of result regardless of forum is one of the objectives of conflicts law. Goonrich, Confrict of LAws, $\S 4$ (3d ed. 1949). 